\title{
THE ABSORPTION INTO AND DISTRIBUTION OF PENICILLIN IN THE CEREBROSPINAL FLUID
}

\author{
By EDITH DUMOFF-STANLEY, HARRY F. DOWLING, AND LEWIS K. SWEET \\ (From the Department of Medicine, George Washington University School of Medicine, Gal- \\ linger Municipal Hospital, Washington, D. C., and the Evans and Haynes Memorials, \\ Massachusetts Memorial Hospitals, and the Department of Medicine, Boston \\ University School of Medicine, Boston, Massachusetts)
}

(Received for publication July 13, 1945)

The slow excretion of penicillin from the cerebrospinal fluid into the blood stream and the fact that no absorption of penicillin took place from the blood stream into the spinal fluid when small doses of penicillin were administered systemically has been demonstrated ( 1 to 4 ). One investigator was unable to find penicillin in the cerebrospinal fluid of patients without central nervous system lesions 30 and 60 minutes after intravenous injection of as much as 30,000 units.

As a result of these observations, penicillin has been employed intrathecally in the treatment of intracranial infections, both experimentally (6 to 8 ) and clinically (9 to 12), and has proved to be of considerable therapeutic value. However, the treatment of intracranial infections with intrathecal penicillin, even in the most skillful hands, is not always easy. It is often difficult to decide how much penicillin to administer intrathecally, how long intrathecal injections must be continued, and whether or not systemic therapy is also necessary. In the more intractable infections, daily intrathecal injections must be continued over long periods of time. Repeated injections of penicillin into the lumbar subarachnoid space not uncommonly cause lumbosacral arachnoiditis and unilteral or bilateral sciatic nerve palsy (13). In some cases, because of the formation of a "block" in the cerebrospinal system, intracisternal and eventually intraventricular administration may become necessary. The dangers of multiple cisternal punctures are (1) hemorrhage into the cisterna magna, (2) needling of the floor on the fourth ventricle, and (3) herniation of the medulla into the cisterna as a result of changes in intracisternal pressure. Recently, we (13) have seen a patient die of hemorrhage into the cisterna magna, caused, in all probability, by the rupture of a vessel by the spinal puncture needle. In addition, the obvious technical difficulties, the discomfort to the patient, and the ever present possibility of introducing secondary infection make it desirable to dispense with the intrathecal administration of penicillin if this should prove feasible.

In the hope of simplifying some of these problems, the following studies were undertaken. Sixteen studies were made using 14 patients. Eight of these, Group A, did not have meningitis. The others, Group B, had definite evidence of intracranial infection. In the majority of these studies, amounts of drug far in excess of the average recommended therapeutic range were used in order to exaggerate anticipated results. The penicillin levels were calculated by the method of Rammelkamp (14). All media contained paraaminobenzoic acid to obviate the action of sulfonamides in cases in which these drugs had been administered.

\section{Group A. Studies in patients without meningitis}

1. Baby R. G. was a 10-pound 7/2-month-old male with miliary tuberculosis. After withdrawing from the lumbar subarachnoid space $10 \mathrm{ml}$. of clear fluid, 5,000 units of penicillin were injected. The spinal fluid was under normal pressure, contained no cells, the Pandy reaction was negative, and the dextrose content normal. One hour later, samples of lumbar fluid, cisternal fluid, ventricular fluid, and venous blood were obtained. The lumbar and cisternal fluids contained at least 20 units of penicillin per $\mathrm{ml}$., the blood serum contained 0.625 units per $\mathrm{ml}$., and the ventricular fluid contained 0.312 units per $\mathrm{ml}$.

Five days later, the same baby was given a single intravenous dose of 20,000 units of penicillin. A ventricular needle was left in situ. Ventricular fluid was drawn at $2,5,10,15,25,45$ and 60 minutes. At 60 minutes, a sample of blood was drawn, and at 65 minutes, a sample of lumbar fluid was drawn. The spinal fluid findings were normal. The first 3 specimens of ventricular fluid contained no penicillin. At 15 minutes, the ventricular fluid contained 0.078 units per $\mathrm{ml}$., and each of the subsequent 3 specimens contained 0.156 units per $\mathrm{ml}$. At 65 minutes, there was no penicillin in the lumbar fluid, although the blood serum level at 60 minutes was at least 20 units per $\mathrm{ml}$. (Figure 1). 


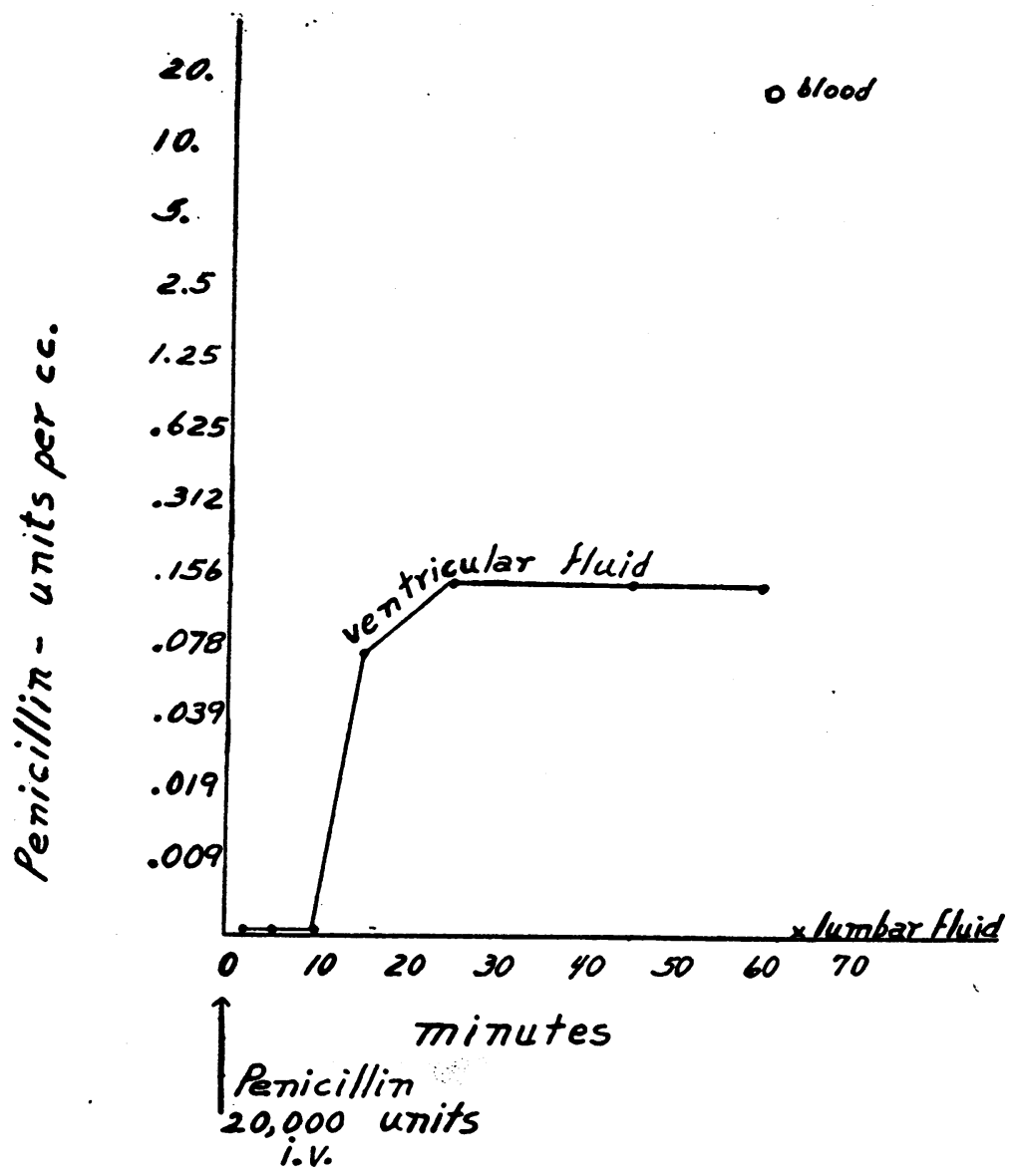

Fig. 1. Penicillin Levers in Body Flutds of Baby R. G., Group A, 1, AFter Single Intravenous InJection of 20,000 UnIts

2. Baby G. G. was an 18-months-old infant with miliary tuberculosis. He received a single intravenous injection of 20,000 units of penicillin. Ventricular and lumbar needles were left in situ, and samples of fluid withdrawn at frequent intervals over a period of 4 hours. Blood samples were drawn every hour. The first 5 samples of ventricular fluid were slightly blood tinged. The remainder, however, were clear and contained no cells, and had negative Pandy reactions. Penicillin appeared in the ventricular fluid before it was detected in the lumbar fluid. Penicillin levels in the ventricular fluid were constantly higher than those in the lumbar fluid, and penicillin was detectable in the ventricular fluid for about 60 minutes after the last measurable level was obtained in the lumbar fluid (Figure 2).

The following 3 patients, 3,4 , and 5 , were utilized while having diagnostic pneumoencephalograms.

3. J. M. was a 49 -year-old, 180 pound male. He received 50,000 units of penicillin intravenously in a single dose. Fifteen minutes later, the first specimen of spinal fluid was withdrawn. Over a period of 40 minutes, 180 $\mathrm{ml}$. of spinal fluid were withdrawn in 4 to $12 \mathrm{ml}$. amounts, at 2- to 5-minute intervals. Equal amounts of air were injected. No penicillin was found in any of the specimens of spinal fluid. Blood levels 15 and 60 minutes after the dose was given were 0.312 and 0.078 units per ml., respectively. The pneumoencephalogram showed moderate enlargement of the ventricles and cortical atrophy.

4. V. H. was a 42-year-old, 125-pound female. She received 50,000 units of penicillin intravenously in a single injection. Thirty-six minutes later, the first spinal fluid was drawn. Seventy-five $\mathrm{ml}$. of spinal fluid were withdrawn in units of 2 to $10 \mathrm{ml}$., at 1 - to 7-minute intervals, over a period totaling 36 minutes. Equal amounts of air were injected to replace the fluid. The last specimen was drawn 72 minutes after the injection of the penicillin. No penicillin was found in the spinal fluid. Blood levels at 18 and 65 minutes were 0.625 units per $\mathrm{ml}$. and none, respectively. The pneumoencephalogram was normal.

5. J. P. was a 13-year-old male with idiopathic epilepsy. He received an intravenous clysis of a solution of 200 units of penicillin per ml., regulated to deliver $3 \mathrm{ml}$. per minute. The initial spinal fluid was drawn 17 minutes after beginning the clysis. A total of $120 \mathrm{ml}$. of fluid 


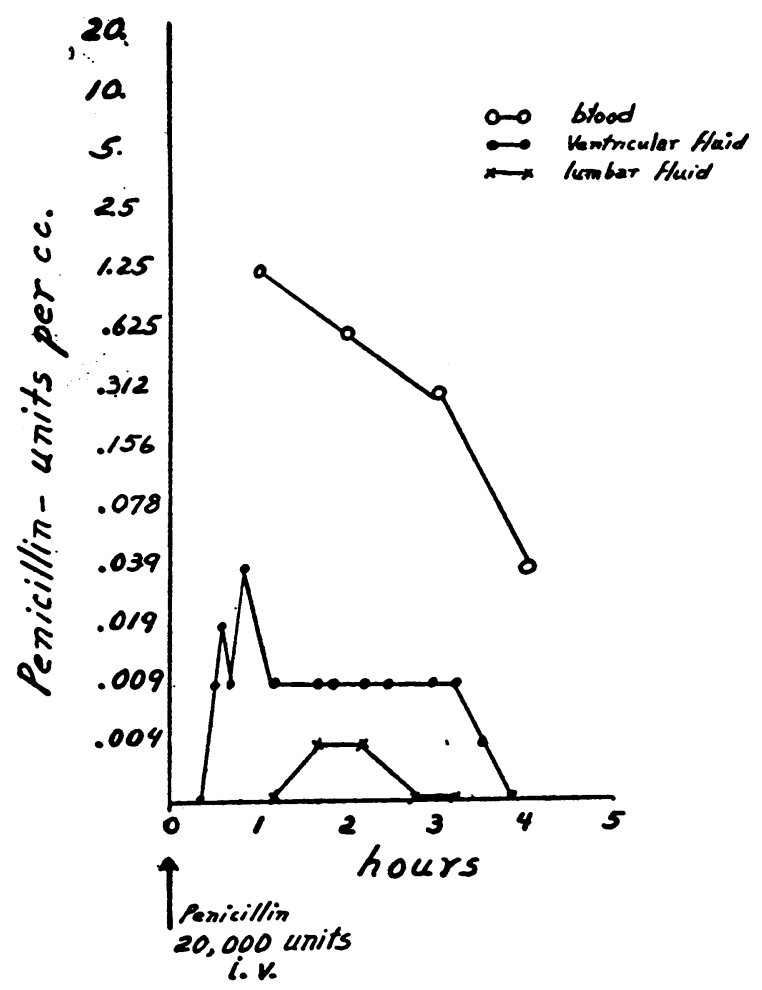

Fig. 2. Penicillin Levels in Body Fluids of Baby G. G., Group A, 2, after Single Intravenous InJecTION OF 20,000 UNITS

was withdrawn in 1 to $10 \mathrm{ml}$. amounts over a total period of 24 minutes. Equal amounts of air were injected. The venoclysis was maintained throughout this procedure. The last 2 specimens of spinal fluid, obtained 39 and 42 minutes after intravenous penicillin was started, contained 0.004 units per $\mathrm{ml}$. Blood levels at 10,30 and 40 minutes were $0.312,0.156$ and 0.312 units per $\mathrm{ml}$, respectively. The pneumoencephalogram showed no abnormality.

6. F. C. was a 61-year-old male with type III pneumococcic pneumonia, which did not respond to sulfamerazine. He received constant intravenous penicillin at 24,000 units per hour. Samples of spinal fluid were drawn 4 hours and 30 minutes, 4 hours and 45 minutes and 5 hours after the clysis was started. No penicillin was found in any of the samples. The spinal fluid findings were within normal limits. Serum concentrations at 4 and 5 hours were 0.039 units per $\mathrm{ml}$.

7. B. G. was a 20-year-old male with subacute bacterial endocarditis due to streptococcus viridans. He received constant intravenous penicillin at 10,000 units per hour. Spinal fluid was drawn 5 hours and 21 minutes, 5 hours and 35 minutes and 6 hours and 4 minutes after beginning therapy. The spinal fluid contained no penicillin, and other findings were within normal limits. Blood levels at 5 and 6 hours from beginning were 0.019 and 0.039 units per ml., respectively.

8. M. S. was a 48-year-old woman with bilateral suppurative parotitis. She was treated for 2 days with sulfamerazine. Hemolytic staphylococcus aureus was isolated from the blood, throat, and pus from the parotids. On the third day, penicillin was started by constant intramuscular clysis at 10,000 units per hour. During the remainder of her course, her spinal fluid pressure ranged between 200 and $250 \mathrm{~mm}$. of water, and each specimen of spinal fluid contained between 200 and 245 red blood cells per cu. mm. Her non-protein nitrogen was 251 mgm. per cent on the day penicillin was started, and continued high until the day of death, when it was $189 \mathrm{mgm}$. per cent. High penicillin levels were obtained in the blood and spinal fluid (Figure 3 ). The patient died suddenly on her seventh hospital day. At autopsy the cause of death was found to be a large pulmonary embolus originating in a thrombosed iliac vein.

\section{Group B. Studies in patients with meningitis}

1. M. D. was a 66-year-old female with meningococcic meningitis. On admission, her spinal fluid contained 14,200 white blood cells per cu. mm., of which 98 per cent were polymorphonuclears. On direct smear, a few gram negative diplococci were seen. She responded poorly to full doses of sulfamerazine. On the fourth day she received, by intravenous drip, a solution of 100 units of penicillin per ml., a total of 100,000 units in 2 hours. Spinal fluid and blood were drawn at 15 and 85 minutes after beginning the clysis. The second spinal fluid contained 0.009 units per $\mathrm{ml}$. The blood levels were 0.312 and 1.25 units per $\mathrm{ml}$., respectively. Sulfamerazine was continued. The patient recovered.

2. E. P., a 27-year-old female, was found on admission to have a spinal fluid which contained 1,100 white blood

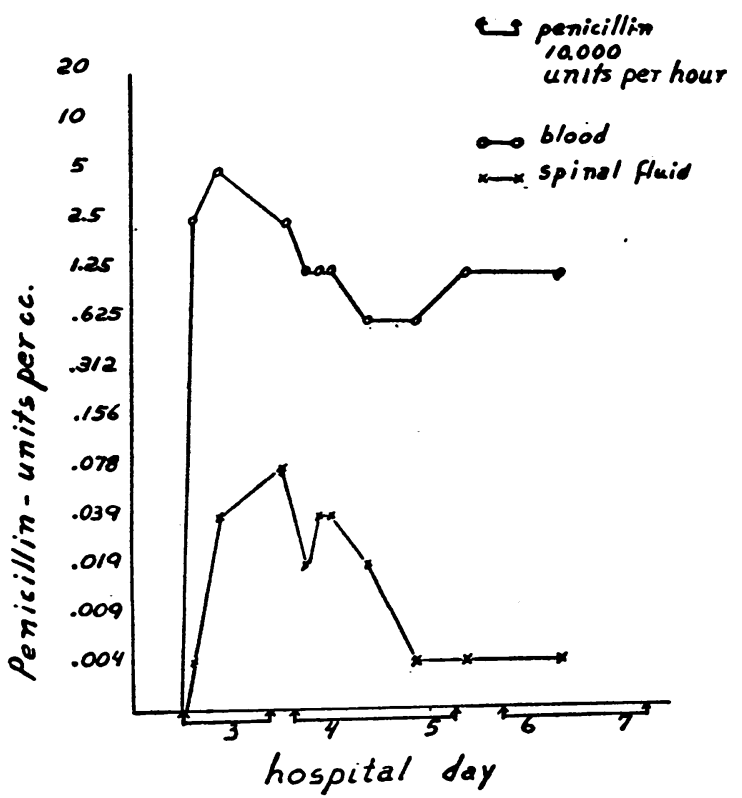

Fig. 3. Penicillin Levels in Body Flums of M. S., Group A, 8, during Constant Intramuscular Clysis OF 10,000 UNITS PER HOUR 


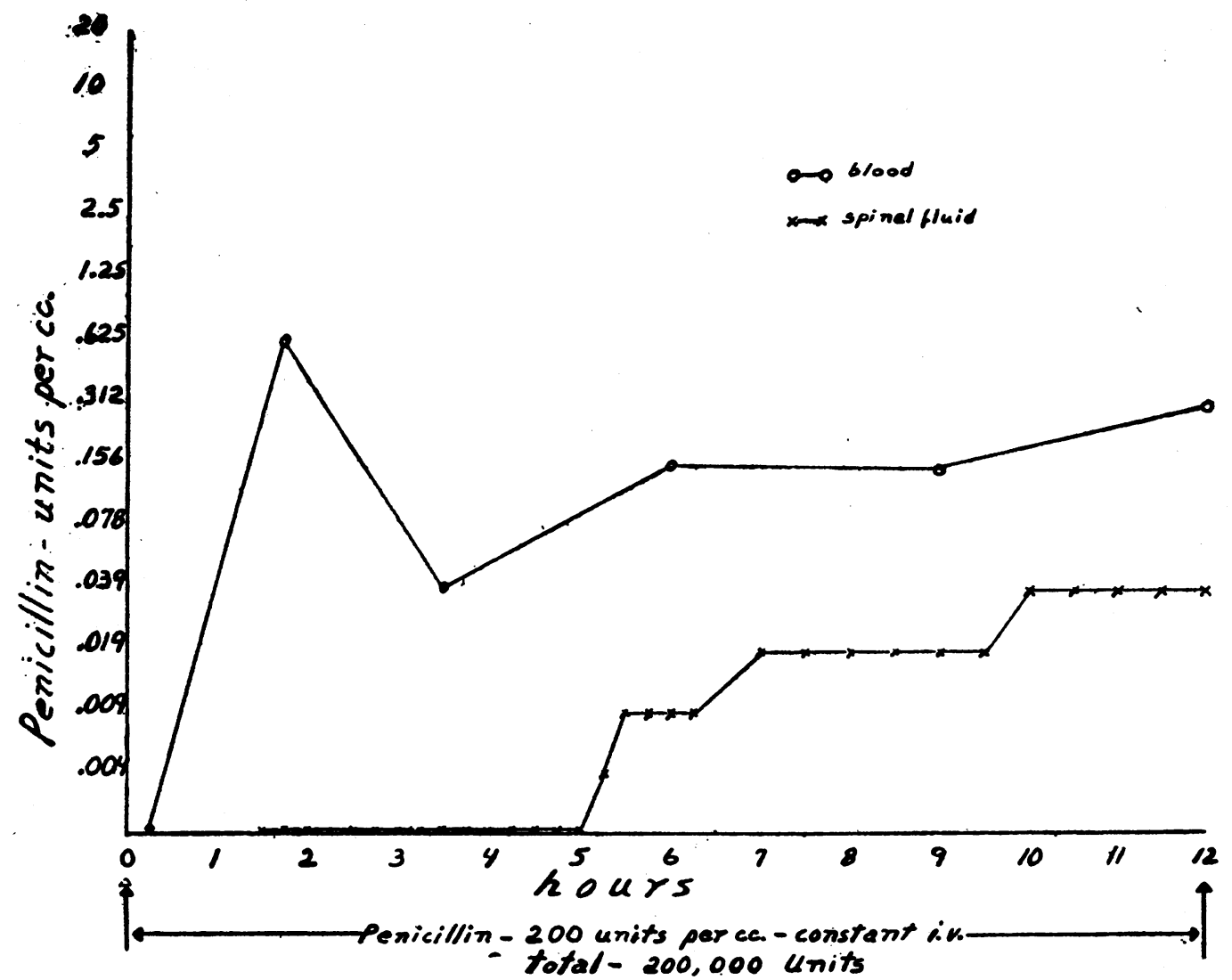

Fig. 4. Penicilin Levels in Body Fluids of E. P., Group B, 2, during Constant Intravenous Infusion of Penicillin

cells per cu. mm., 80 per cent lymphocytes. On her third day, her spinal fluid contained 710 white blood cells per cu. mm., of which 97 per cent were lymphocytes. On this day, she received a constant intravenous infusion of a solution of $\mathbf{2 0 0}$ units of penicillin per $\mathrm{ml}$. over a period of 12 hours, a total of 200,000 units. During this period, a needle was left in the lumbar subarachnoid space, and $2 \mathrm{ml}$. of spinal fluid were withdrawn every 15 to $30 \mathrm{~min}$ utes. Samples of blood were drawn at 2-hour intervals. In the spinal fluid, penicillin was first detected in the sample drawn 5 hours from the beginning of the infusion, and subsequent samples contained constantly increasing amounts of penicillin. The serum concentrations remained fairly constant (Figure 4). The patient's condition did not change. On the eighth day, when her spinal fluid contained 392 lymphocytes per cu. mm., an attempt was made to repeat the study. She was restless, submitted to the procedures for only a short period, and repeated venipunctures were impossible. She received 250 $\mathrm{ml}$. of a solution of 200 units per $\mathrm{ml}$. of penicillin by constant intravenous drip, over a period of 2 hours and $15 \mathrm{~min}$ utes. One sample of blood, obtained 30 minutes after beginning the drip, contained 0.019 units per $\mathrm{ml}$. Five samples of spinal fluid were drawn at one-half hour intervals. The last 2 specimens, drawn $1 \%$ and $2 \%$ hours from beginning the infusion, contained 0.009 units of penicillin per $\mathrm{ml}$. Autopsy, 11 days later, revealed miliary tuberculosis with tuberculous meningitis.

3. B. J. was a 17-year-old female with benign lymphocytic choriomeningitis. Her admission spinal fluid contained 1,550 white cells per cu. mm., 90 per cent lymphocytes, normal sugar, and increased protein. On the second day of her illness, she received 200,000 units of penicillin by constant intravenous drip of a solution of 200 units per $\mathrm{ml}$. for a period of 8 hours. During this time, $2 \mathrm{ml}$. of spinal fluid were drawn every one-half hour and a specimen of blood every 2 hours. No penicillin was found in any of the spinal fluid samples, the blood levels ranged from 0.039 to 0.156 units per $\mathrm{ml}$.

4. E. G., a 23-year-old female, was admitted with signs of meningitis. Her admission spinal fluid contained 7,380 white blood cells per cu. mm., 95 per cent polymorphonuclears, increased protein, and normal sugar. All spinal fluid and blood cultures were sterile. Sulfomamide therapy was started on the day of admission. On the second day, when her spinal fluid contained 2,955 cells per cu. mm., 95 per cent polymorphomuclears, she received 650 $\mathrm{ml}$., by constant intravenous drip, of a solution of $\mathbf{2 0 0}$ units of penicillin per ml., over a period of 5 hours and 15 minutes. Two milliliters of spinal fluid were drawn 
every 15 minutes, and a specimen of blood every hour. There was no penicillin in the spinal fluid, and the blood levels fell from 0.312 to 0.009 unit per $\mathrm{ml}$. during the procedure.

5. M. H., a 20-year-old female, had severe meningococcic meningitis. Her admission spinal fluid contained 13,600 polymorphonuclear cells per cu. mm., no sugar, increased protein, and many group I meningococci, typed directly. For the first 24 hours, the patient received 60,000 units of penicillin every 2 hours, the second 24hour period 50,000 units every 3 hours, and for the third 24 hours 30,000 units every 3 hours, intramuscularly. At the end of the third day, penicillin was discontinued and oral sulfamerazine started. She made a complete recovery. Serum concentration of penicillin, at 16 and 32 hours after treatment was started, was 5 units per $\mathrm{ml}$. The blood for these determinations was drawn immediately before giving the next intramuscular dose. Table I summarizes the spinal fluid findings.

6. L. S., a 17-year-old girl, had hemolytic staphylococcus aureus bacteremia. Before admission, she had received 5.5 grams of sulfadiazine. On admission, her temperature was $104.8^{\circ} \mathrm{F}$., she was stuporous and restless, her neck was stiff, and Kernig's sign was present. Her cerebrospinal fluid contained 46 cells per cubic millimeter, of which 80 per cent were polymorphonuclear cells and 20 per cent lymphocytes. On the second day, there were 1,500 polymorphonuclear cells per cu. mi. of spinal fluid. Sulfadiazine was continued by clysis. On the second day, penicillin was begun by constant intramuscular clysis at 10,000 units per hour. The spinal fluid continued to show increased cells, from 286 to 595 per cu. mm., with 90 per cent or more polymorphonuclears. On the day penicillin was started the non-protein nitrogen was $61 \mathrm{mgm}$. per cent and continued to rise thereafter, reaching a height of $116 \mathrm{mgm}$. per cent. The patient expired on the seventh day. Autopsy revealed acute endocarditis and multiple abscesses to all viscera including the brain. Figure 5 demonstrates the high penicillin levels obtained.

\section{RESULTS AND DISCUSSIONS}

As shown in Table II, measurable amounts of penicillin were found in the lumbar subarachnoid fluid of 6 patients who received the drug by the

TABLE I

Spinal fuid findings of patient $M$. $H$., group $B, 5$, during administration of penicillin by intermittent intramuscular injection

\begin{tabular}{|c|c|c|c|}
\hline $\begin{array}{l}\text { Hours from } \\
\text { onset of } \\
\text { therapy }\end{array}$ & $\begin{array}{l}\text { White } \\
\text { blood } \\
\text { count }\end{array}$ & $\begin{array}{l}\text { Organisms } \\
\text { in direct } \\
\text { smear }\end{array}$ & $\begin{array}{c}\text { Penicillin } \\
\text { concentration } \\
\text { units }\end{array}$ \\
\hline $\begin{array}{c}0 \\
6 \frac{1}{2} \\
.15 \\
30 \frac{1}{2}\end{array}$ & $\begin{array}{c}\text { per cx. mm. } \\
13,400 \\
11,200 \\
30,200 \\
3,800\end{array}$ & $\begin{array}{c}\text { numerous } \\
\text { numerous } \\
\text { numerous } \\
\text { few }\end{array}$ & $\begin{array}{l}\text { per } m l . \\
\\
0.019 \\
0.019 \\
0.009\end{array}$ \\
\hline
\end{tabular}

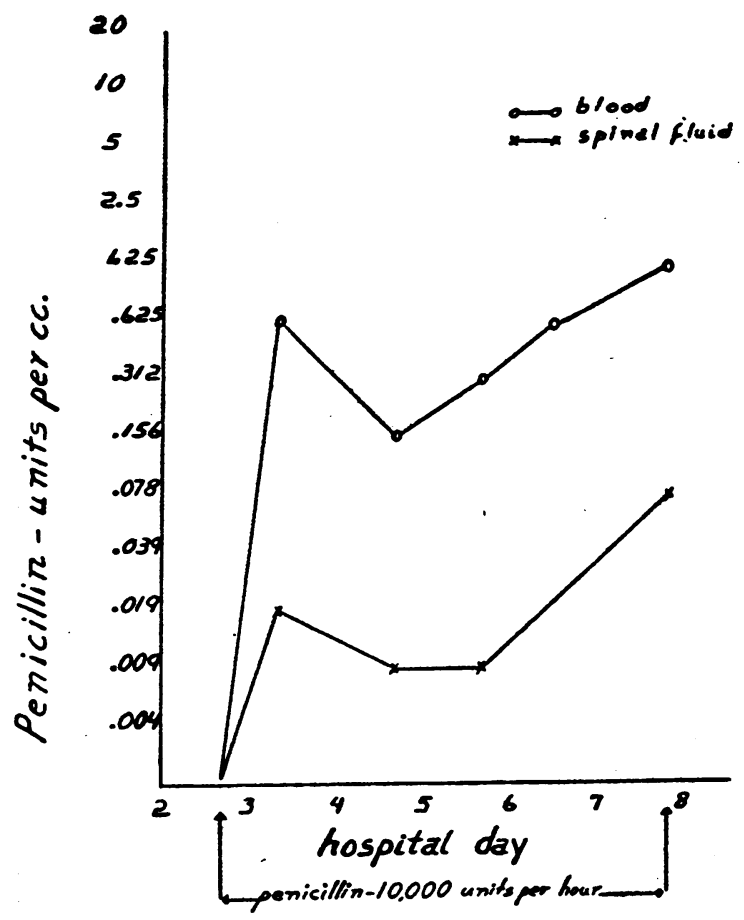

Fig. 5: Penicillin Levels in Body Fluids of L. S., Group B, 6, during Constant Intramuscular Clysis OF 10,000 UNITS PER Hour

intravenous or intramuscular route. All of these patients had a maximal serum penicillin concentration of 0.625 units per $\mathrm{ml}$., or over (disregarding the single determination in the second study of patient E. P., Group B, 2), 5 of them having a maximal concentration of 1.25 units per ml. or more. Six of the remaining 8 subjects showed no penicillin in the cerebrospinal fluid at any time. One of these 6 had a maximal serum penicillin concentration of 0.625 units per ml. for a short time, while the concentration of penicillin in the serum of the other 5 was consistently below that figure. It will also be noted from Table II that, where high serum levels are obtained, the longer the period of time during which penicillin is administered systemically, the greater is the possibility that penicillin will be found in the lumbar fluid. In general, the drug had been administered longer to the patients who showed penicillin in the lumbar subarachnoid fluid than to those who failed to achieve detectable concentrations. Furthermore, in the 3 studies which showed the lowest concentrations in the lumbar fluids, G. G. (Group A, 2), M. D. (Group B, 1), and E. P. (Group B, 


\begin{tabular}{|c|c|c|c|c|c|c|}
\hline \multirow[b]{2}{*}{ Patient } & \multicolumn{2}{|c|}{$\begin{array}{l}\text { Greatest penicillin con- } \\
\text { centration in: }\end{array}$} & \multirow[b]{2}{*}{$\begin{array}{l}\text { Intracranial } \\
\text { infection }\end{array}$} & \multirow[b]{2}{*}{$\begin{array}{l}\text { Mode of } \\
\text { administration }\end{array}$} & \multicolumn{2}{|c|}{$\begin{array}{l}\text { Time from onset of penicillin } \\
\text { administration to withdrawal of: }\end{array}$} \\
\hline & $\begin{array}{l}\text { Blood } \\
\text { serum }\end{array}$ & $\begin{array}{l}\text { Cerebrospinal } \\
\text { fluid }\end{array}$ & & & $\begin{array}{c}\text { First specimen } \\
\text { of cerebrospinal } \\
\text { fluid with } \\
\text { highest } \\
\text { penicillin } \\
\text { concentration }\end{array}$ & $\begin{array}{l}\text { Last specimen } \\
\text { of lumbar fluid }\end{array}$ \\
\hline $\begin{array}{l}\text { R. G. Group A, } 1 \\
\text { G. G. Group A, 2* }\end{array}$ & $\begin{array}{r}20.00 \\
1.25\end{array}$ & $0.156 \ddagger$ & $\begin{array}{l}\text { None } \\
\text { None }\end{array}$ & $\begin{array}{l}\text { I.V. single dose } \\
\text { I.V. single dose }\end{array}$ & $25 \mathrm{~min}$. & \\
\hline $\begin{array}{l}\text { J. P. Group A, } 5 \\
\dot{M} . \text { D. Group B, } 1\end{array}$ & $\begin{array}{l}0.312 \\
1.25\end{array}$ & $\begin{array}{l}0.004 \\
0.004 \ddagger \\
0.009\end{array}$ & $\begin{array}{l}\text { None } \\
\text { Meningococcic }\end{array}$ & $\begin{array}{l}\text { I.V. clysis } \\
\text { I.V. clysis }\end{array}$ & $\begin{array}{l}90 \mathrm{~min} . \\
39 \mathrm{~min} . \\
85 \mathrm{~min} .\end{array}$ & $\begin{array}{l}4 \text { hours } \\
42 \text { min. } \\
85 \text { min. }\end{array}$ \\
\hline E. P. Group B, 2† & 0.625 & 0.039 & Tuberculous & I.V. clysis & 10 hours & 12 hours \\
\hline M. H. Group B, 5 & $\begin{array}{l}0.019 * * \\
5.0\end{array}$ & $\begin{array}{l}0.009 \\
0.019\end{array}$ & $\begin{array}{l}\text { Meningococcic } \\
\text { meningitis }\end{array}$ & $\begin{array}{l}\text { I.V. clysis } \\
\text { I.M. intermittent }\end{array}$ & $\begin{array}{l}1 \frac{3}{4} \text { hours } \\
15 \text { hours }\end{array}$ & $\begin{array}{r}21 \text { hours } \\
30 \frac{1}{2} \text { hours }\end{array}$ \\
\hline L. S. Group B, 6 & 1.25 & 0.078 & Multiple brain & I.M. clysis & 120 hours & 120 hours \\
\hline $\begin{array}{l}\text { M. S. Group A, } 8 \\
\text { J. M. Group A, } 3 \\
\text { V. H. Group A, } 4 \\
\text { F. C. Group A, } 6 \\
\text { B. G. Group A, 7 } \\
\text { B. J. Group B, } 3\end{array}$ & $\begin{array}{l}5.0 \\
0.312 \\
0.625 \\
0.039 \\
0.039 \\
0.156\end{array}$ & $\begin{array}{l}0.078 \\
0 \\
0 \\
0 \\
0 \\
0\end{array}$ & $\begin{array}{l}\text { None } \\
\text { None } \\
\text { None } \\
\text { None } \\
\text { None } \\
\text { Lymphocytic }\end{array}$ & $\begin{array}{l}\text { I.M. clysis } \\
\text { I.V. single dose } \\
\text { I.V. single dose } \\
\text { I.V. clysis } \\
\text { I.V. clysis } \\
\text { I.V. clysis }\end{array}$ & 24 hours & $\begin{array}{l}96 \text { hours } \\
55 \text { min. } \\
72 \text { min. } \\
5 \text { hours } \\
6 \text { hours } \\
8 \text { hours }\end{array}$ \\
\hline E. G. Group B, 4 & 0.312 & $\mathbf{0}$ & $\begin{array}{l}\text { Meningitis of un- } \\
\text { known etiology }\end{array}$ & I.V. clysis & & $5 \frac{1}{t}$ hours \\
\hline
\end{tabular}

2 , second study) had received penicillin for shorter periods ( 4 hours, 85 minutes, and 21/4 hours, respectively) than any of the other patients who showed detectable amounts of the drug in the lumbar fluid.

Penicillin was present in the ventricular fluid when none was present in the subarachnoid fluid in the 2 infants, R. G. and G. G. (Group A, 1 and 2). In J. P. (Group $A, 5$ ), a very small concentration was found in the final $4 \mathrm{ml}$. of a total of $120 \mathrm{ml}$. of fluid withdrawn for pneumoencephalogram. These last few ml. of fluid were undoubtedly from the ventricles. These results suggest that penicillin administered systemically may pass from the circulating blood into the cerebrospinal fluid primarily through the choroid plexus into the lateral ventricles.

With the exception of patients L. S. (Group B, 6) and M. S. (Group A, 8), unusually high serum concentrations were due to administration of very large amounts of penicillin. Patients L. S. and M. S. obtained high serum concentrations on the commonly recommended dose for bacteremia,
10,000 units per hour. Both patients were proved by autopsy to have severe renal damage. The kidneys of L. S. were grossly enlarged and riddled with numerous tiny petechiae and small pinpoint abscesses. In addition, the left kidney contained 2 infarcts, one 4 by $3 \mathrm{~cm}$., the other smaller, the central portions of which were liquified. The kidneys of $M$. S. were not remarkable grossly, showing only edema. Microscopically, however, there was extensive vacuolation and destruction of the tubular epithelium and deposits of calcium within the lumina of the damaged tubules. In both these cases, therefore, high serum concentrations of penicillin and relatively high spinal fluid concentrations were apparently the result of slow excretion of the drug by severely damaged kidneys (15).

Other investigators $(16,17)$ have found, in cases of meningitis, that small amounts of penicillin will penetrate the spinal fluid from the blood stream. Therapeutic levels of penicillin have been demonstrated in the spinal fluids of 8 patients with meningitis, 60 to 125 minutes after the injection 
of a single intravenous or intramuscular dose and the conclusion was drawn that if adequate systemic penicillin could be given, intrathecal therapy might be unnecessary (16). One case of pneumococcic meningitis which recovered on systemic treatment alone has been reported (9). Our studies indicate that very large doses of penicillin must be administered and high serum concentrations maintained for several hours before penicillin can be detected in the lumbar subarachnoid fluid. Even under these conditions, a concentration of penicillin which is within accepted therapeutic limits is not always obtained. On the basis of the present investigations and the experience of ourselves and others in the treatment of patients with meningitis, it is concluded that the systemic administration of penicillin in the doses commonly employed will not consistently yield adequate concentrations of penicillin in the lumbar subarachnoid fluid.

\section{SUMMARY AND CONCLUSIONS}

1. Sixteen studies were made of absorption of penicillin into the cerebrospinal fluid in 14 patients.

2. Penicillin was present in the subarachnoid fluid of 6 patients during intravenous or intramuscular administration of penicillin. Four of these patients showed evidence of disease of the meninges.

3. No patient with serum concentration of less than 0.625 units per ml., and no patient who had penicillin in his blood stream for less than 12 hours, obtained concentrations in his spinal fluid which might be considered therapeutically effective.

4. It is concluded that the systemic administration of penicillin in the doses commonly employed will not consistently yield measurable concentrations of penicillin in the spinal subarachnoid fluid.

Drs. B. R. Robertson and T. L. Hickman of the Department of Pediatrics, and Dr. A. G. Revilla of the Department of Neurology of Gallinger Municipal Hospital lent their assistance to this project. We wish to thank Dr. Walter Freeman of the Department of Neurology of George Washington University School of Medicine for his cooperation and suggestions.

\section{BIBLIOGRAPHY}

1. Rammelkamp, C. H., and Keefer, C. S., The absorption, excretion, and toxicity of penicillin administered by intrathecal injection. Am. J. M. Sc., 1943, 205, 342.

2. Rammelkamp, C. H., and Keefer, C. S., The absorption, excretion, and distribution of penicillin. J. Clin. Invest., 1943, 22, 425.

3. Fleming, Alexander, Streptococcus meningitis treated with penicillin. Lancet, 1943, 2, 434.

4. Florey, H. W., Discussion at Royal Society of Medicine. Brit. M. J., 1943, 2, 654.

5. Herrell, W. E., The clinical use of penicillin. J.A. M.A., 1944, 124, 622.

6. Pilcher, C., and Meachem, W. F., The chemotherapy of intracranial infections: III. The treatment of experimental staphylococcic meningitis with intrathecal administration of penicillin. J.A.M.A., 1943, 123, 330 .

7. Pilcher, C., and Meachem, W. F., Chemotherapy of intracranial infections; treatment of pneumococcal meningitis by intracranial administration of penicillin. J. Neurosurg., 1944, 1, 76.

8. Evans, A. L., The treatment of intracranial infections with penicillin. J.A.M.A., 1944, 124, 641.

9. Dawson, M. H., and Hobby, G. L., The clinical use of penicillin: Observation in one hundred cases. J.A.M.A., 1944, 124, 611.

10. Keefer, C. S., Blake, F. G., Marshall, E. K., Jr., Lockwood, J. S., and Wood, W. Barry, Jr., Penicillin in the treatment of infections. J.A.M.A., 1943, 122, 1218.

11, 12. Hartford, C. G., Martin, S. P., Hageman, P. O., and Wood, W. Barry, Jr., The treatment of staphylococcic, pneumococcic, gonococcic and other infections with penicillin. J.A.M.A., 1945, 127, 253 and 325.

13. Sweet, L. K., Dumoff-Stanley, E., Dowling, H. F., and Lepper, M. F., The treatment of pneumococcic meningitis with penicillin. J.A.M.A., 1945, 127, 263.

14. Rammelkamp, A method for determining the concentration of penicillin in body fluids and exudates. Proc. Soc. Exper. Biol. and Med., 1942, 51, 95.

15. Rammelkamp, C. H., and Bradley, S. E., Excretion of penicillin in man. Proc. Soc. Exper. Biol. and Med., 1943, 53, 30.

16. Rosenberg, D. H., and Sylvester, S. C., The excretion of penicillin in the spinal fluid in meningitis. Science, 1944, 100, 32.

17. Cooke, J. V., and Goldring, D., The concentration of penicillin in the various body fluids during penicillin therapy. J. A. M. A., 1945, 127, 80. 